\title{
Resistance of Rye Seedlings to Drought and Freeze-Thaw Stress
}

\author{
Guozhang Bao ${ }^{1 *}$, Xinyu Pan ${ }^{1}$, Bairu Yan², Yixin Chang ${ }^{1}$, Wenyi Tang ${ }^{1}$, \\ Yan Qu ${ }^{1}$, Jin $\mathrm{Wei}^{3}$, Hongwei Zhao ${ }^{4}$
}

${ }^{1}$ Key Laboratory of Groundwater Resources and Environment of the Ministry of Education (Jilin University); Jilin Provincial Key Laboratory of Water Resources and Environment; College of New Energy and Environment, Jilin University, Changchun, 130012 China

${ }^{2}$ Environmental Monitoring Center Station of Jilin Province

${ }^{3}$ College of Instrumentation \& Electrical Engineering, Jilin University, Changchun, China

${ }^{4}$ The Administration of Jingyu Water Conservation

Received: 16 June 2021

Accepted: 27 September 2021

\begin{abstract}
The freeze-thaw (FT) and drought in early spring in Northeast China are two main ecological stresses to forage grasses. In this paper, Secale cereale L. grown under 2 d drought-stress (mild, moderate, and severe treat) with 5, 10 and $15 \%$ polyethylene glycol (PEG-6000) concentrations. The temperature gradient was set to $10,5,0,-5,0,5$ and $10^{\circ} \mathrm{C}$ after FT treatment. The content of protein, soluble sugar and MDA increased with a trend of combined stress $>$ FT $>$ drought stress, indicating that the damage of rye under single FT stress was higher than that under the single drought stress. Under drought stress, FT could aggravate the damage to rye. At $\mathrm{T} 7\left(10^{\circ} \mathrm{C}\right)$ in the thawing stage, compared with the CK, the pattern of the decrease of RWC and chlorophyll and the increase of protein and MDA content was severe combined stress $>$ FT $>$ moderate combined stress $>$ moderate drought stress. The results of this study showed that a proper drought treatment before FT stress could alleviate the physiological damage to the forage leaf.
\end{abstract}

Keywords: ecological stresses, PEG-6000, physiological response, seedlings

\section{Introduction}

Secale cereale L., as a common cold-season forage, is a perennial herb belonging to the rye widely planted in temperate regions due to its rapid growth and high yield $[1,2]$. It can be planted in a cold temperate zone, temperate zone and subtropical zone, because of its

e-mail: baogz@jlu.edu.cn strong stress resistance and cold tolerance in spring $[3,4]$. In China, it is mainly planted between the east of $107^{\circ} \mathrm{E}$ and $25^{\circ} \mathrm{N}-27^{\circ} \mathrm{N}$, and the vernalization can be completed at the low temperature of $-5 \sim 0^{\circ} \mathrm{C}[5,6]$.

Plants can be threatened by various biological and abiotic stresses, including water, temperature, salinity and light. Plants living at high latitudes or altitudes often experience freeze-thaw(FT) cycles in winter and early spring and cold tolerance in winter is one of the limiting factors for plant survival [7]. Being exposed to sub-zero temperatures often results in injury 
and death [8]. Several cell-level dysfunctions caused by cold stress include membrane damage, production of reactive oxygen species, protein denaturation and accumulation of toxic products [9, 10]. Kendall and McKersie [11] provided evidence of oxidative stress induced by FT such as accumulation of reactive oxygen species (ROS) which can damage protein and make it denaturated [12, 13], and Min et al. [14] pointed out that MDA accumulated more in frozen samples at $-4.5^{\circ} \mathrm{C}$ than at $-4.0^{\circ} \mathrm{C}$. Therefore, the study of frost resistance of plants under variable temperature conditions is helpful to elucidate the physiological adaptation mechanism of plants under seasonal variable temperature conditions.

Drought is the main abiotic stress in arid and semiarid regions of the world, which seriously affects the yield and quality of crops [15-17]. Drought causes a series of physiological changes in plants. Plants adapt to drought stress through physiological adaptation and develop a wide range of physiological drought resistance mechanisms [18-21]. Plants exposed to drought stress lead to a decrease in relative water content [22, 23], Riedell [24] pointed out that the RWC of the leaves of plants not infected by aphids decreased significantly at the end of drought stress. The chlorophyll content of two species of spring wheat decreased after drought stress [25]. With the increase of drought stress, the chlorophyll content of two soybean varieties decreased [26]. Drought stress usually leads to the decrease of Soluble sugar (SS) content in Rhodiola variegata and Casuarina equisetifolia mediated by arbuscular mycorrhizal fungi [27-29]. PEG 6000 solution was used in the formulation of water stress. Yigit et al. [30] results showed increased water stress and reduce the percentage of germination in all species. PEG applications have been used in many species to identify their resistance to drought and it has given successful results. All studies conducted until now have proved that the increasing water stress decreases the germination proper. In addition, it has also been proven in the previously conducted studies that the tolerances of different origins to drought stress are different [31].

Plant physiological stress is a complex interaction between plants and the environment. Under natural conditions, the environmental impact of only a single factor without the interaction of complex stress factors will not occur [16]. Therefore, this research aims to study the changing pattern of RWC, protein, chlorophyll, SS and MDA contents in leaves of the seedlings under combined FT and drought stresses in high latitude, to reveal the physiological response characteristics of Secale cereale L., and to provide a reference for the range management.

\section{Experimental}

\section{Experimental Materials and Methods}

Rye seeds (Secale cereale L. cv. Dongmu 70) were sterilized with $0.1 \% \mathrm{KMnO}_{4}$ for 2 hours, washed with deionized water, evenly spread (25 grains per row $\mathrm{x}$ 20 rows $)$ in a tray containing wet filter paper $(20 \mathrm{~cm} \mathrm{x}$ $30 \mathrm{~cm}$ ), and cultured in a light incubator (MGC-450BP light incubator). The growth of seeds was observed every day. The seeds were ventilated properly. The temperature was $25^{\circ} \mathrm{C}$ during the day and $20^{\circ} \mathrm{C}$ at night. The light intensity (PPFD) was about $280 \mu \mathrm{mol} \mathrm{m} \mathrm{m}^{-2} \mathrm{~s}^{-1}$ $(66 \%)$ for $12 \mathrm{~h}$. Hoagland nutrient (including $4 \mathrm{mM}$

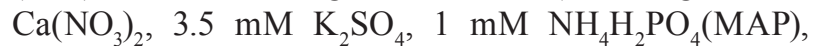
$4.1 \mathrm{Mm} \mathrm{MgSO}_{4}, 5 \times 10^{-2} \mathrm{mM}$ Fe-Na EDTA, $5 \times 10^{-2} \mathrm{mM}$ $\mathrm{FeSO}_{4}, 5 \times 10^{-2} \mathrm{mM} \mathrm{H}_{3} \mathrm{BO}_{3}, 1 \times 10^{-2} \mathrm{mM} \mathrm{Na}_{2} \mathrm{~B}_{4} \mathrm{O}_{7}, 1 \times 10^{-2} \mathrm{mM}$ $\mathrm{MnSO}_{4}, 3 \times 10^{-4} \mathrm{mM} \mathrm{CuSO}_{4}, 1 \times 10^{-3} \mathrm{mM} \mathrm{ZnSO}_{4}, 2 \times 10^{-4} \mathrm{mM}$ $\left.\left(\mathrm{NH}_{4}\right)_{2} \mathrm{SO}_{4}\right)$ was used every day to keep seeds wet. The simulation of the drought and FT stresses was carried out after 7 days of incubation.

\section{PEG Drought Simulation Treatment}

Using the above Hoagland nutrient solution to prepare PEG solution [32-34]. Four concentrations of PEG $(5,10,15$ and 20\%) were set up in the pre-test to simulate drought treatment. The results showed that the lethal rate of plant leaves was about $70 \%$ under the $20 \%$ PEG concentration. Therefore, 5\% (mild drought, D1), $10 \%$ (moderate drought, D2), 15\% (severe drought, D3) were selected in this experiment. The seedlings with the same growth were treated with mild, moderate and severe drought for $2 \mathrm{~d}$.

\section{Freeze-Thaw Treatment}

LT50 (semi-lethal temperature) indicates the resistance to FT stress, which results in 50\% injury or plant death $[14,35]$. Rye seedlings treated with different drought stress were subjected to FT stress. In the pre-test, the lethal rate of Rye was $50 \%$ when the temperature was $-5^{\circ} \mathrm{C}$. After $2 \mathrm{~d}$ of drought treatment, the seedlings were placed in the BPHJ-120A test box for FT stress treatment. During the freezethaw treatment, the seedlings have been under drought stress. The FT temperature gradually changed under programmed control for $14 \mathrm{~h}$. The FT temperature was sampled every $2 \mathrm{~h}$ at $10,5,0,-5,0,5$ and $10^{\circ} \mathrm{C}$ (T1-T7) [36, 37], and the non-freeze-thaw treatment (include CK, D1, D2, D3) was placed in a light incubator to simulate natural growth conditions (12 $\mathrm{h}$ day/night). The experiment was divided into eight treatment groups: CK-control group; D1-mild drought; D2-moderate drought; D3-severe drought; F-Freeze and thaw; FD1-FT + mild drought; FD2-FT + moderate drought; FD3-FT + severe drought. At each temperature, eight treatment groups were randomly sampled with three replicates.

\section{Measurement}

Relative water content (RWC) of leaves was measured by saturated weighing method [38]. Took fresh leaves and weighed the fresh weight (Wf) (0.3 g 
sample (about 10 seedlings) was taken); then immersed them in water for $24 \mathrm{~h}$ until water absorption was saturated. After taking them out, used filter paper to absorb surface water and weigh the fresh matter (Wt). Finally, put the samples into the oven that has been heated up to $105^{\circ} \mathrm{C}$ for 15 minutes, and then dried them at $80^{\circ} \mathrm{C}$ to constant weight and weighed the dry matter (Wd).

$$
R W C=\frac{\left(W_{f}-W_{d}\right)}{\left(W_{t}-W_{d}\right)} \times 100 \%
$$

Soluble protein content was determined by Coomassie Brilliant Blue method [39-41]. Weighed $0.1 \mathrm{~g}$ fresh sample ( $0.1 \mathrm{~g}$ samples (3 to 5 seedlings) of the different treatments) and ground into homogenate with $5 \mathrm{ml}$ distilled water. After centrifugation for 10 minutes at $3000 \mathrm{r} / \mathrm{min}$, the supernatant was reserved. After extracting $1.0 \mathrm{ml}$ sample and fivefold dilution, taking $1.0 \mathrm{ml}$ into the test tube. Each sample was repeated twice. $5 \mathrm{ml}$ Coomassie Brilliant Blue G-250 solution was added to shake the sample. The absorbance was determined by colorimetry at $595 \mathrm{~nm}$ wavelength, and the protein content was determined by standard curve.

The content of chlorophyll (Chl) was determined by SPAD-502 Plus chlorophyll meter.

The contents of SS and malondialdehyde (MDA) were determined by thiobarbituric acid method [3941]. Weighed $0.5 \mathrm{~g}$ fresh sample $(0.5 \mathrm{~g}$ sample (about 15 seedlings) selected randomly), added $5 \mathrm{ml} 10 \%$ trichloroacetic acid (TCA), ground to homogenate, and centrifuged for 10 minutes at $4000 \mathrm{r} / \mathrm{min}$. Absorbing centrifugal supernatant $2 \mathrm{ml}$ (CK plus $2 \mathrm{ml}$ distilled water), adding $2 \mathrm{ml} 0.6 \%$ thiobarbituric acid (TBA), put the mixture into boiling water bath for 15 minutes and cooled rapidly. With distilled water as blank sample, the extinction at 532, 600 and $450 \mathrm{~nm}$ wavelength was determined.

\section{Statistical Analysis}

All results with the experiment were expressed as a mean of 3 replicates. Microsoft Excel 2007 and SPSS 19.0 were used for data processing and one-way ANOVA. The minimum significant difference method was used to test the different significance at $\mathrm{P}=0.05$ significance level. Origin 8.0 software was used for mapping. All the results were presented by mean $\pm \mathrm{SE}$.

\section{Results and Discussion}

\section{Effects of Freeze-Thaw and Drought Stress on RWC}

RWC of rye decreased under either drought, FT or combined stress (Fig. 1). Compared with CK, RWC decreased as FD3 $>$ FD1 $>$ F $>$ FD $2>$ D $3>$ D2 $>$ D1 in the frozen stage and T4 (Fig. 1). Compared with CK, RWC in D1, D2 and D3 groups decreased by 1.6, 6.5, $11.6 \%$; F group by $17.7 \%$, FD1, FD 2 and FD3 groups by $18.2,15.0$ and $23.0 \%$, respectively (Fig. 1). At T7, compared with $\mathrm{T} 1$, the RWC of rye leaves treated by FT stress could not reach the level of T1, although the temperature at $\mathrm{T} 7$ was restored to the initial stage.

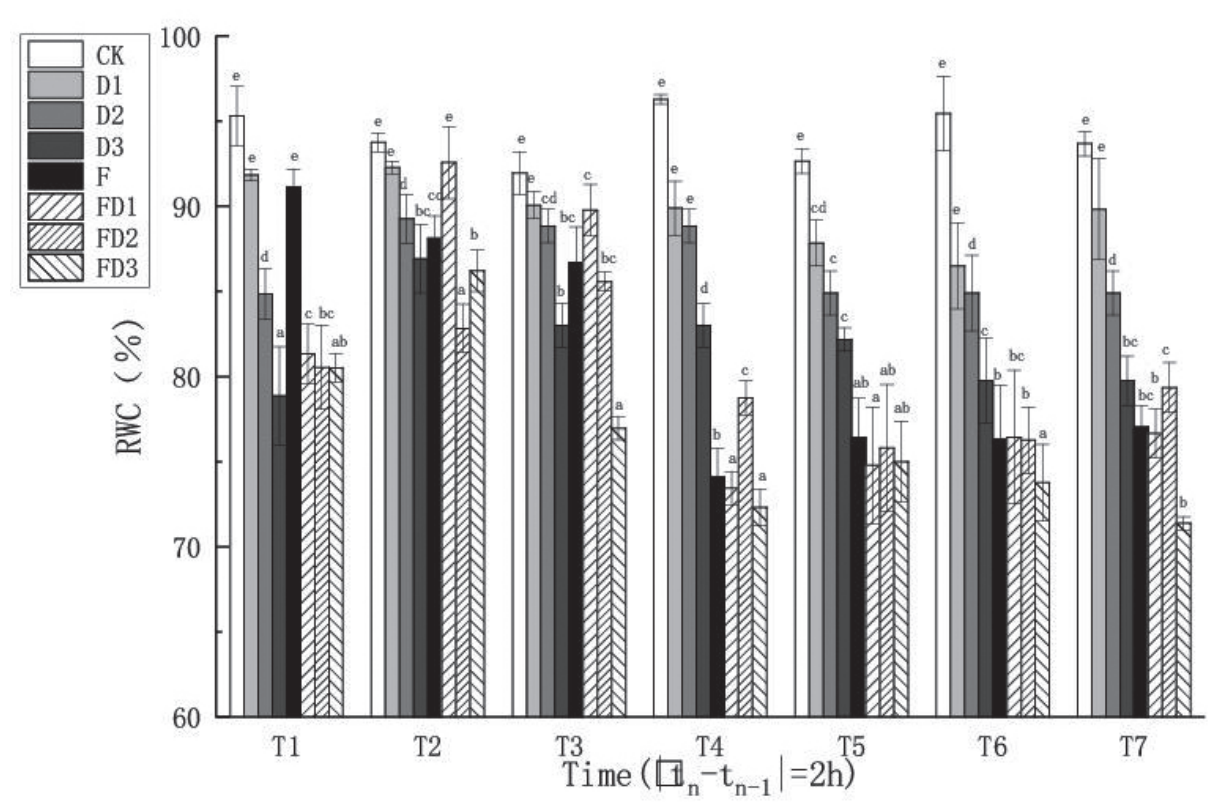

Fig. 1. Effects of freeze-thaw, mild (1), moderate (2) and severe (3) drought stress on RWC of rye seedlings. T1-T7 represents 2-14h respectively, corresponding to seven temperature gradients; D1, D2 and D3 represent mild, moderate and severe drought respectively; F represents Freeze-thaw. The different letters indicated the significant difference between different treatments at the same temperature $(\mathrm{P}<0.05)$. The data are expressed as mean $(+$ standard error $)(\mathrm{n}=3)$. 


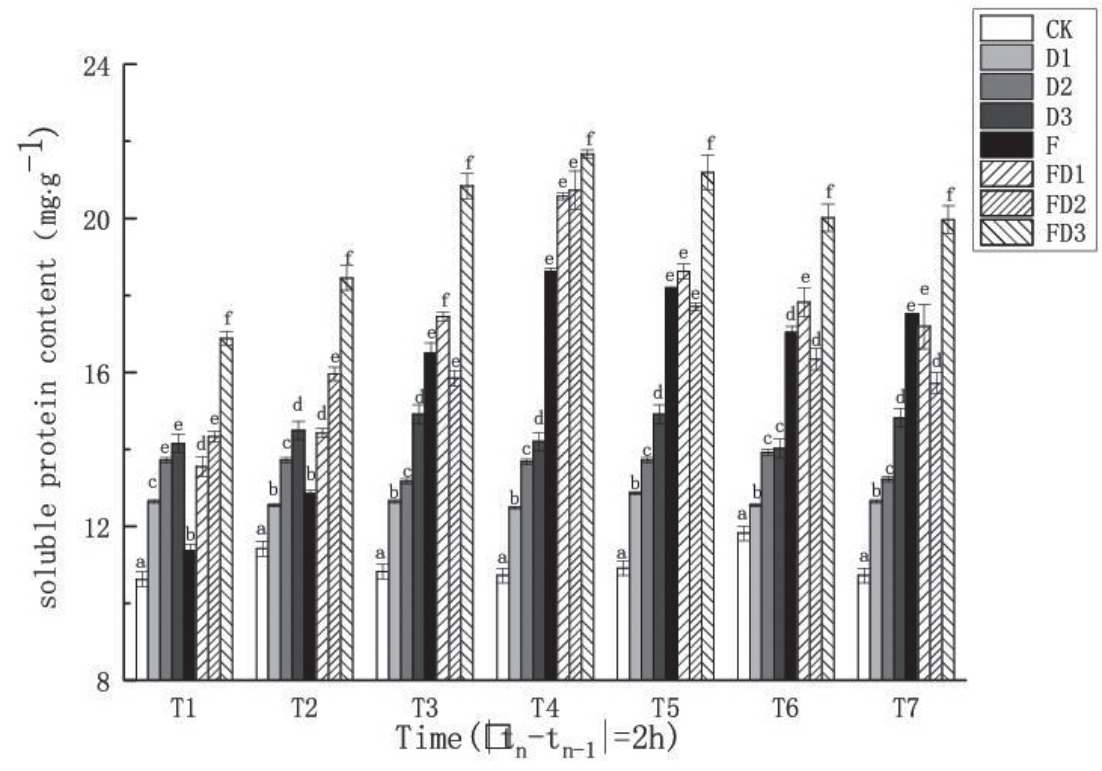

Fig. 2. Effects of freeze-thaw, mild (1), moderate (2) and severe (3) drought stress on RWC of rye seedlings. T1-T7 represents 2-14h respectively, corresponding to seven temperature gradients; D1, D2 and D3 represent mild, moderate and severe drought respectively; F represents Freeze-thaw. The different letters indicated the significant difference between different treatments at the same temperature $(\mathrm{P}<0.05)$. The data are expressed as mean (+standard error) $(\mathrm{n}=3)$.

\section{Effects Of Freeze-Thaw And Drought Stress on Soluble Protein Content}

The protein content of rye increased under drought, FT and combined stresses. The protein content of rye increased first and then decreased slowly under FT and combined stresses, and reached the maximum at T4 (Fig. 2). Compared with CK, protein content in $\mathrm{T} 4$ stage increased with the trend of $\mathrm{FD} 3>\mathrm{FD} 2>\mathrm{FD} 1>\mathrm{F}>\mathrm{D} 3>\mathrm{D} 2>\mathrm{D} 1$ (Fig. 2). At $\mathrm{T} 7$ stage, compared with $\mathrm{CK}$, the protein content of D1, D2 and D3 increased by $24.2,19.1$ and $33.1 \%$ respectively under single drought stress, and the protein content of F, FD1, FD2 and FD3 increased by 44.1, 40.5, 36.3 and $52.1 \%$ respectively (Fig. 2). At T7, compared with $\mathrm{T} 1$, regardless that the FT group regained its initial

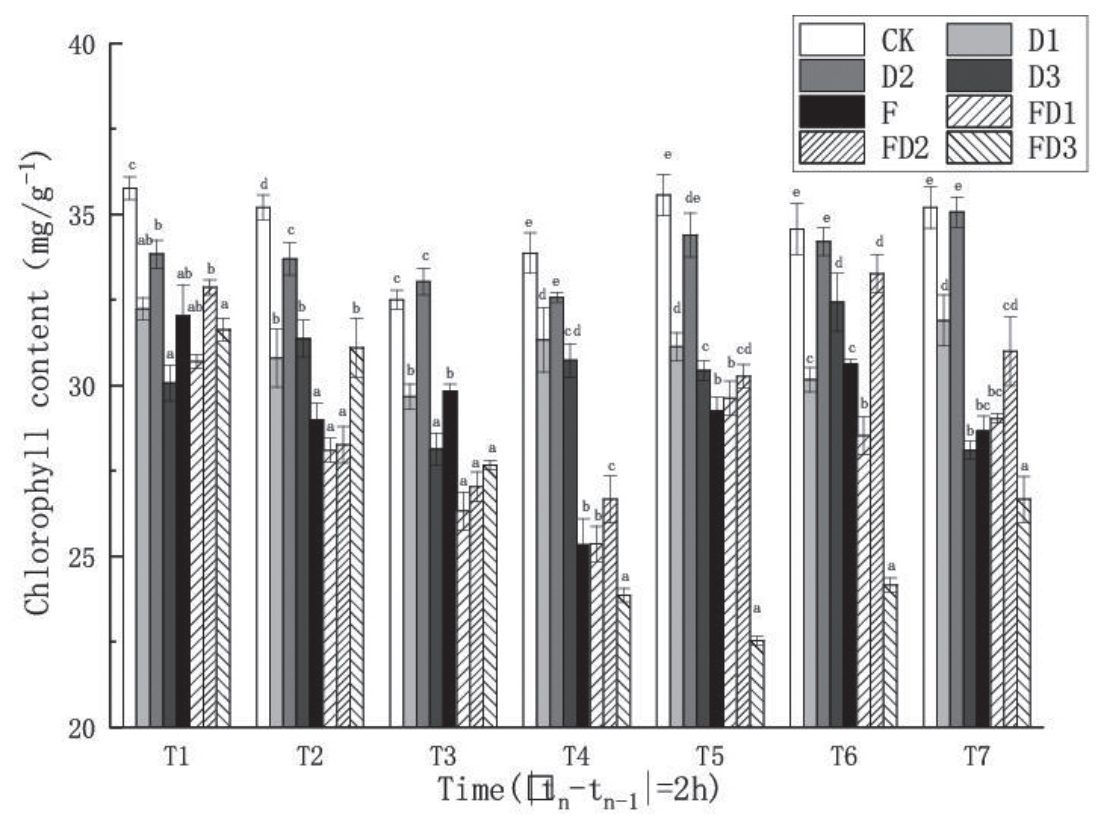

Fig. 3. Effects of freeze-thaw, mild (1), moderate (2) and severe (3) drought stress on RWC of rye seedlings. T1-T7 represents 2-14 h respectively, corresponding to seven temperature gradients; D1, D2 and D3 represent mild, moderate and severe drought respectively; $\mathrm{F}$ represents Freeze-thaw. The different letters indicated the significant difference between different treatments at the same temperature $(\mathrm{P}<0.05)$. The data are expressed as mean $(+$ standard error $)(\mathrm{n}=3)$. 
temperature, the protein content after FT stress was higher than that at T1, and the FD2 protein content had the least increase with a value of $9.6 \%$.

\section{Effects Of Freeze-Thaw and Drought Stress on Chlorophyll Content}

Except for group D2 of T3, compared with CK, the chlorophyll (Chl) content of rye decreased under drought, FT and combined stresses, decreased first and then gradually recovered under combined stresses (Fig. 3). In T4 stage, compared with $\mathrm{CK}$, Chl decreased as $\mathrm{FD} 3>\mathrm{F}, \quad \mathrm{FD} 1>\mathrm{FD} 2>\mathrm{D} 3>\mathrm{D} 1>\mathrm{D} 2$ (Fig. 3). The $\mathrm{Chl}$ content of F, FD1 and FD2 reached the minimum at T4, while FD3 reached the minimum at T5. In T7 stage, compared with CK, Chl content decreased by 11.3, 2.1 and $27.3 \%$ respectively under drought stress, while D2 decreased insignificantly. Chl contents of F, FD1, FD2 and FD 3 decreased by 26.3, 22.6, 17.8 and 35.7\% respectively (Fig. 3). Compared with $\mathrm{T} 1$, the $\mathrm{Chl}$ content in FT group decreased after FT stress, regardless of the temperature at $\mathrm{T} 7$ returned to the initial stage, which was similar to that in RWC.

\section{Effects Of Freeze-Thaw and Drought Stress on Soluble Sugar Content}

Compared with CK, SS content increased except T1 (Fig. 4). Compared with CK, the increase of SS content at $\mathrm{T} 4$ showed a trend of $\mathrm{FD} 3>\mathrm{FD} 2>\mathrm{FD} 1>\mathrm{F}>\mathrm{D} 3>\mathrm{D} 2>\mathrm{D} 1$ (Fig. 4). The SS content of FD2 reached the maximum at T4, while both F and FD3 reached the maximum at T5. Compared with CK, SS content increased by 1.35 ,
4.4 and $22.2 \%$ under drought stress $(\mathrm{p}<0.05)$, and increased by 30.1, 40.1, 40.6 and $50.1 \%$ under FT and combined stress, respectively $(\mathrm{p}<0.05)$. At $\mathrm{T} 7$, although the temperature was restored to the initial stage, the SS content increased after FT stress, and the increase in FD2 group was the least, which was similar to the change of protein.

\section{Effects Of Freeze-Thaw And Drought Stress on MDA Content}

Compared with CK, MDA content of rye increased under drought, FT and combined stress, and MDA content increased first and then decreased under the combined stress (Fig. 5). At T4, compared with CK, the increase of MDA content tended to be FD3 $>$ FD2 $>$ FD1 $>$ F $>$ D $3>$ D2 $>$ D1, and reached the maximum at T4 in FD3 group (Fig. 5). Compared with CK, MDA content increased by $21.0,14.8$ and $29.5 \%$ under drought stress at T7 (Fig. 5). At T7, although the temperature of T7 returned to the initial stage, MDA content of F, FD1 and FD3 still increased while FD2 decreased after FT treatment.

\section{Correlation Analysis}

Pearson correlation analysis of five indexes of rye seedlings showed that under the single FT stress and combined stress, there were positive relationships between either SS and MDA, or SS and MDA $(p<0.05)$; there were negative relationships among RWC and protein content, SS and MDA, protein content and $\mathrm{Cl}$, Chl and SS and Chl and MDA $(\mathrm{p}<0.05)$ (Table 1, 2).

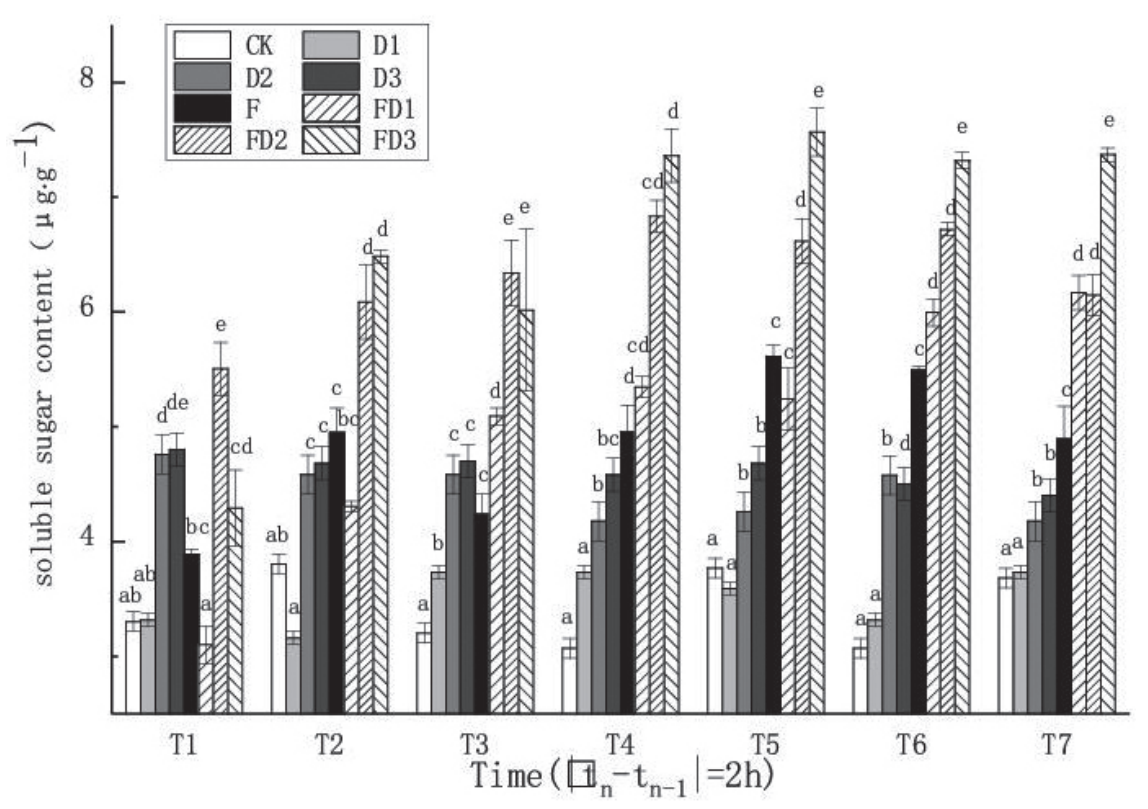

Fig. 4. Effects of freeze-thaw, mild (1), moderate (2) and severe (3) drought stress on RWC of rye seedlings. T1-T7 represents 2-14 h respectively, corresponding to seven temperature gradients; D1, D2 and D3 represent mild, moderate and severe drought respectively; F represents Freeze-thaw. The different letters indicated the significant difference between different treatments at the same temperature $(\mathrm{P}<0.05)$. The data are expressed as mean $(+$ standard error $)(\mathrm{n}=3)$. 


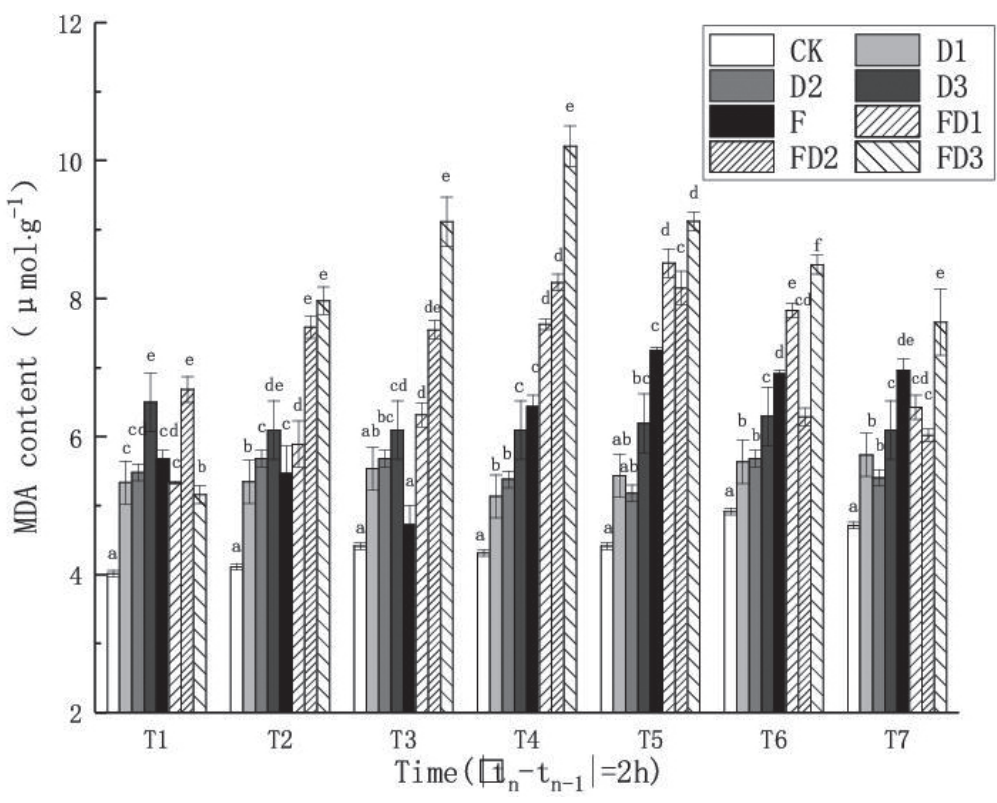

Fig. 5. Effects of freeze-thaw, mild (1), moderate (2) and severe (3) drought stress on RWC of rye seedlings. T1-T7 represents 2-14h respectively, corresponding to seven temperature gradients; D1, D2 and D3 represent mild, moderate and severe drought respectively; F represents Freeze-thaw. The different letters indicated the significant difference between different treatments at the same temperature $(\mathrm{P}<0.05)$. The data are expressed as mean $(+$ standard error $)(\mathrm{n}=3)$.

RWC was positively correlated with Chl under single FT stress $(\mathrm{p}<0.01, \mathrm{r}=0.554)$ (Table 1), except the combined stress (Table 2); Chl and SS were not correlated under the single FT stress (Table 1), but negatively correlated under the combined one $(\mathrm{p}<0.01$, $\mathrm{r}=-0.447)$ (Table 2).

\section{Discussion}

RWC is an important index reflecting leaf water stress and affecting plant water relationships [42], showing the degree of water deficit of plants under stress [43]. Drought stress further reduces the RWC of wheat and rice [44]. Flexas et al. [45] concluded that the

Table 1. Pearson correlation analysis between the indices when the temperature returns to the initial stage under single freeze-thaw stress.

\begin{tabular}{|c|c|c|c|c|c|}
\hline & RWC & Protein & Chl & SS & MDA \\
\hline RWC & 1 & $-0.870^{* *}$ & $0.554^{* *}$ & $-0.792^{* *}$ & $-0.853^{* *}$ \\
\hline Protein & & 1 & $-0.596^{* *}$ & $0.821^{* *}$ & $0.907^{* *}$ \\
\hline Chl & & & 1 & -0.244 & $-0.692^{* *}$ \\
\hline SS & & & & 1 & $0.710^{* *}$ \\
\hline MDA & & & & & 1 \\
\hline
\end{tabular}

*Correlation is significant at the 0.05 level. **Correlation is significant at the 0.01 level, $\mathrm{n}=3$.

Table 2. Pearson correlation analysis between the indices when the temperature returns to its initial stage under combined stress.

\begin{tabular}{|c|c|c|c|c|c|}
\hline & RWC & Protein & Chl & SS & MDA \\
\hline RWC & 1 & $-0.707^{* *}$ & 0.331 & $-0.547^{* *}$ & $-0.599^{* *}$ \\
\hline Protein & & 1 & $-0.675^{* *}$ & $0.667^{* *}$ & $0.667^{* *}$ \\
\hline Chl & & & 1 & $-0.447^{*}$ & $-0.513^{* *}$ \\
\hline SS & & & & 1 & $0.817^{* *}$ \\
\hline MDA & & & & & 1 \\
\hline
\end{tabular}


RWC of soybean and tobacco decreased under water stress. The results showed that the RWC of rye leaves decreased under drought stress (Fig. 1). At this time, the water deficit of leaves reduced and with the increase of drought stress, RWC gradually decreased (Fig. 1), The degree of leaf water deficit gradually deepened. According to the research of Cui et al. (2016), the RWC of leaves decreases gradually with the prolongation of drought duration, i.e. the deepening of drought degree. RWC decrease first and then increased gradually under FT stress, which may be due to the dehydration of water considering that the frozen cells in plant cells may lead to a significant decrease in RWC when the temperature was below $0^{\circ} \mathrm{C}$. When the temperature rose, the cells rehydrated and RWC gradually increased [46]. At T4 and T7, RWC decreased dramatically under the combined stress than under the single drought one, possibly because the change of leaf temperature may be an important factor controlling leaf water status [44]. At T4 and T7, the decrease of RWC showed a trend of severe combined stress $>$ mild combined stress $>$ FT stress $>$ moderate combined stress, which indicated that mild drought and severe drought treatment aggravated the decline of RWC under FT stress, and moderate drought treatment alleviated the impact of freeze-thaw on RWC. Compared with $\mathrm{T} 1$, although the temperature of $\mathrm{T} 7$ returned to the initial stage, the physiological damage to seedlings caused by FT stress was severe.

Soluble proteins play an important role in the osmotic regulation of plant cells. When plants are exposed to environmental stress, they can induce the production of multiple reactive oxygen species (ROS) [47]. Excessive accumulation of ROS may directly damage the proteins [48]. The results showed that the protein content increased under drought stress [49]. Under adversity conditions, the balance of ROS production and removal will be disrupted, causing plant damage. There are many studies on the effects of drought stress on osmotic adjustment substances. It is generally believed that when plants lack water, the soluble protein content will increase to a certain extent, thereby increasing the drought adaptability of the plant [50]. With the deepening of drought stress, the protein content increased gradually, indicating that the more serious the drought was, the more damage to the seedlings. Balestrasse et al. [32] showed that cold treatment could significantly increase protein content. The increase of protein content during the freeze-thaw period in the lower temperature stage and the decrease in the higher temperature stage may be due to the production of injury-related proteins induced by freeze to reduce the damage to seedlings. At the thawing stage, seedlings were favorable for recovery from freezing, and the content of injury-related proteins decreases [46]. Combined stress increase the protein content, however, at the stage of temperature recovery, the FD2 protein content was lower than that of $\mathrm{F}$ group, suggesting that reasonable control of water before FT stress may accelerate the decrease of soluble protein content, which is conducive to the recovery of physiological properties of rye. Compared with T1, the effect of FT stress on protein was irreversible, although the temperature of T7 stage was restored to the initial stage.

In photosynthesis, chlorophyll is the basic factor and power of plant growth and biomass production. The stability of chlorophyll during adversity allows cells to maintain functional chloroplasts so that photosynthesis can be restored after plants recover from adversity [51]. Chlorophyll content in leaves is an important trait affecting seedling growth rate under cold conditions [52]. Low temperature and drought stress can damage chloroplast matrix [53], ROS damage [54], and ultimately reduce photosynthesis. Chl content was lower under low temperature and drought stress [55]. The results showed that the $\mathrm{Chl}$ content of rye decreased under drought stress, and the Chl content of rye further decreased under moderate drought stress. Under FT stress, Chl decreased with the decrease of temperature, showing a trend of decreasing first and increasing slowly. At T7, the Chl content under single severe drought stress (D3) was lower than that under single FT stress(F), which indicated that the damage of severe drought to rye was greater than that under FT stress. The combined stress accelerated the decline of Chl, however, at $\mathrm{T} 7$, the content of $\mathrm{Chl}$ tended to increase under $\mathrm{F}$ stress compared with either mild or moderate drought treatment, indicating that a moderate drought treatment before FT stress was helpful to improve the resistance of rye.

The soluble sugar in plant leaves, as a major osmotic regulator, could promote vitrification (a phenomenon in which intracellular water hardens like glass during freezing or cold stress without ice crystallization), thus avoiding damage caused by crystallization when water withdraws [56, 57]. Plants respond to water shortage and adapt to water shortage because of the accumulation of osmotic regulators, which are related to stress tolerance [58]. It is reported that under natural conditions, the SS content increases when plants are exposed to low temperature, and decreases with temperature rises. Cold acclimation can induce combined accumulation to protect cells from frostbite [10] and proteins from freezing and dehydration [59]. The results showed that SS content in leaves of rye seedlings increased under different stress treatments, and increased with the increase of drought stress. At the T4 and T7 stages, the increase of SS content under FT stress was greater than that under the drought one, indicating that the damage degree of rye under the single FT stress was greater than that under the single drought one, and rye accumulated more combined to resist the stress. Under drought stress, SS content increased more efficiently under FT stress than that without it.

The SS content of FD2 reached the maximum at T4 and decreased gradually at the thawing stage, while both $\mathrm{F}$ and FD3 reached the maximum at T5 stage, indicating that the damage to rye by freezing and thawing was still accumulating despite of the increase 
of temperature, and moderate drought treatment was helping to alleviate the damage caused by freezing and thawing and improve the freezing resistance of rye. Compared with T1, the effect of FT stress on rye was irreversible, although the temperature at $\mathrm{T} 7$ returned to the initial stage.

MDA is the final product of lipid peroxidation in the plant cell membrane. The content of MDA can reflect the degree of plant damage. The results showed that MDA content increased under the drought stress, which was consistent with the results of Talaat et al. [60]. Freeze-thaw stress leads to excessive accumulation of ROS, which leads to oxidative stress $[14,61]$, and oxidative damage is also expressed on cell membranes through an accumulation of MDA [14]. Rye accumulated more MDA at T4 than at T3, which was similar to the results of Min et al. [14] that the plants accumulated more MDA at $-4.5^{\circ} \mathrm{C}$ than at $-4^{\circ} \mathrm{C}$. At T3-T7, MDA content increased first and then decreased under FT stress, probably because the damage of leaves was induced by frostbite, and then recovered after temperature compensation [62], so the MDA content decreased after temperature rose. At T7, MDA content increased with a pattern of severe combined stress $>$ FT stress $>$ moderate combined stress $>$ moderate drought stress, probably because the moderate drought stress promoted the improvement of FT tolerance of rye $[59,63]$, so MDA content was lower.

Pearson correlation analysis showed that under the single FT and the combined stress, the protein was positively correlated with SS and MDA, and SS was also positively correlated with MDA, indicating that under the single FT and the combined stress, cell membrane lipid peroxidation leads to an increase in MDA content, and rye accumulated more combined to protect cells and protein from frostbite under low temperature. RWC was negatively correlated with protein, SS and MDA, in addition, protein and $\mathrm{Chl}$ as well as $\mathrm{Chl}$ and SS, MDA had the same correlation, which indicated that low temperature caused water freezing in leaf cells, which lead to water stress, so RWC decreased. What's more, membrane lipid peroxidation resulted in cell function damage and chlorophyll content decrease.

\section{Conclusions}

In our research, drought and FT stress can lead to oxidative stress, i.e. the accumulation of reactive oxygen species, which can lead to oxidative stress in proteins, membrane lipids and other cellular components. The results showed that drought stress and FT stress could decrease the relative water content and chlorophyll content of leaves, at this moment, the water retention capacity of the leaves reduced, and increase the content of protein, SS and MDA to adjust the cell turgor pressure and osmotic potential to alleviate the damage of rye seedlings under drought stress. When the temperature dropped to the lowest point, the damage degree of rye under single FT stress was higher than that under single drought one, and FT stress could aggravate the damage of rye under drought stress. When the temperature rose to $10^{\circ} \mathrm{C}$, the relative water content and chlorophyll content of rye leaves treated by FT stress were lower than those of T1, and the contents of protein, SS and MDA (except FD2 group) were higher than those of T1. It showed that although the temperature returned to the initial stage, the damage of FT stress to rye was irreversible. The damage caused by drought and FT on seedlings showed a trend of severe combined stress $>$ FT stress $>$ moderate combined stress $>$ moderate drought stress, which indicated that the moderate drought treatment under FT conditions might help alleviate the physiological damage of FT on leaves. In the range management of high latitude and highaltitude areas, appropriate water control of forage grass in the early stage of spring and autumn freezing and thawing can effectively alleviate the damage caused by large fluctuations of temperature to plants by improving their physiological adaptation mechanism, avoiding a large number of deaths when plants are exposed to variable temperatures, and improving the survival rate.

\section{Acknowledgments}

This work was sponsored by the National Natural Science Foundation of China (Grant Nos. 31772669 and 32071874), Key Projects of Science and Technology Development Plan of Jilin Province (Grant No. 20210203001SF), Interdisciplinary Project of Jilin University (Grant No. JLUXKJC2020107) and the 111 Project(B16020)

\section{Conflict of Interest}

The authors declare no conflict of interest.

\section{References}

1. CASLER MICHAEL D., DUNCAN RONNY R. Turfgrass biology, genetics, and breeding, John Wiley \& Sons. 1976.

2. FORSTER L., GRANT J., MICHEL T., NG C., BARTH S. Growth under cold conditions in a wide perennial ryegrass panel is under tight physiological control. PeerJ 6, e5520. 2018.

3. GAO Y.T. Dongmu 70 with high yield and good quality. Rural. Agriculture. Farmers (A Edition) 2003, 24, 2003 [In Chinese].

4. MA, WANG, H., LI KC. Study on feeding effect of Dongmu 70 rye on dairy cows. Heilongjiang Animal Science and Veterinary Medicine, 33-35, 2007 [In Chinese].

5. GONG Z., CHEN W., BAO G., SUN J., DING X., FAN C. Physiological response of Secale cereale L. seedlings under freezing-thawing and alkaline salt stress. Environ Sci Pollut Res Int 27, 1499, 2020. 
6. WANG, MING. Assessment of E-Service Quality via E-Satisfaction in E-Commerce Globalization. Electronic Journal on Information Systems in Developing Countries 11, 1, 2003.

7. EWERS F.W., LAWSON M.C., BOWEN T.J., DAVIS S.D. Freeze/thaw stress in Ceanothus of southern California chaparral. Oecologia 136, 213, 2003.

8. BOROCHOV A., WALKER M.A., KENDALL E.J., PAULS K.P., MCKERSIE B.D. Effect of a freeze-thaw cycle on properties of microsomal membranes from wheat. Plant Physiol 84, 131, 1987.

9. BOWERS MC. Environmental effects of cold on plants. Plant-Environment Interactions. Marcel Dekker, New York, 391, 1994.

10. MA, YUANYUAN, ZHANG, YALI, JIANG, LU, SHAO, HONGBO. Roles of plant soluble sugars and their responses to plant cold stress. African Journal of Biotechnology 8. 2008.

11. KENDALL, EDWARD J., MCKERSIE, BRYAN D. Free radical and freezing injury to cell membranes of winter wheat. Physiologia Plantarum 76, 86, 1989.

12. FRIDOVICH, IRWIN. Molecular oxygen: friend and foe. Active oxygen/oxidative stress and plant metabolism, 1, 1991.

13. MITTLER R. Oxidative stress, antioxidants and stress tolerance. Trends Plant Sci 7, 405, 2002.

14. MIN K., CHEN K.T., ARORA R. Effect of short-term versus prolonged freezing on freeze-thaw injury and post-thaw recovery in spinach: Importance in laboratory freeze-thaw protocols. Environmental and Experimental Botany 106, 124, 2014.

15. GOODARZIAN GHAHFAROKHI, MARYAM MANSURIFAR, SYRUS, TAGHIZADEH-MEHRJARDI, RUHOLLAH, SAEIDI, MOHSEN JAMSHIDI, AMIR MOHAMMAD GHASEMI, ELAHE. Effects of drought stress and rewatering on antioxidant systems and relative water content in different growth stages of maize (Zea mays L.) hybrids. Archives of Agronomy and Soil Science 61, 493, 2014.

16. SOBHKHIZI, ALIREZA, RAYNI, MF, BARZIN, HOSSEIN BADIE, NOORI, MOHSEN. Influence of drought stress on photosynthetic enzymes, chlorophyll, protein and relative water content in crop plants. International Journal of Biosciences 5, 89, 2014.

17. SOLTYS-KALINA D., PLICH J., STRZELCZYK-ZYTA D., SLIWKA J., MARCZEWSKI W. The effect of drought stress on the leaf relative water content and tuber yield of a half-sib family of ,Katahdin'-derived potato cultivars. Breed Science 66, 328, 2016.

18. AZAD, KUMKUM, KAMINSKYJ, SUSAN. A fungal endophyte strategy for mitigating the effect of salt and drought stress on plant growth. Symbiosis 68, 73, 2015.

19. KASIM, WEDAD A., OSMAN, MOHAMMED E., OMAR, MOHAMMED N., ABD EL-DAIM, ISLAM A., BEJAI, SAROSH, MEIJER, JOHAN. Control of Drought Stress in Wheat Using Plant-Growth-Promoting Bacteria. Journal of Plant Growth Regulation 32, 122, 2012.

20. KOCHEVA K.V., GEORGIEV G.I., KOCHEV V.K. An improvement of the diffusion model for assessment of drought stress in plant tissues. Physiol Plant 150, 88, 2014.

21. SUN X.G., SHI J., DING G.J. Combined effects of arbuscular mycorrhiza and drought stress on plant growth and mortality of forage sorghum. Applied Soil Ecology 119, 384, 2017.

22. EGILLA J.N., DAVIES F.T., BOUTTON T.W. Drought stress influences leaf water content, photosynthesis, and water-use efficiency of Hibiscus rosa-sinensis at three potassium concentrations. Photosynthetica 43, 135, 2005.

23. SIDDIQUE M.R.B., HAMID A., ISLAM M.S. Drought stress effects on water relations of wheat. Botanical Bulletin of Academia Sinica 41, 35, 2000.

24. RIEDELL, WALTER E. Effects of Russian wheat aphid infestation on barley plant response to drought stress. Physiologia Plantarum 77, 587, 1989.

25. PRASAD P.V.V., PISIPATI S.R., MOMCILOVIC I., RISTIC Z. Independent and Combined Effects of High Temperature and Drought Stress During Grain Filling on Plant Yield and Chloroplast EF-Tu Expression in Spring Wheat. Journal of Agronomy and Crop Science 197, 430, 2011.

26. GUO S.J., YANG K.M., HUO J., ZHOU Y.H., WANG Y.P., LI G.Q. Influence of drought on leaf photosynthetic capacity and root growth of soybeans at grain filling stage. Journal of Applied Ecology 26, 1419, 2015.

27. MANOHARAN P.T., SHANMUGAIAH V., BALASUBRAMANIAN N., GOMATHINAYAGAM S., SHARMA M.P., MUTHUCHELIAN K. Influence of AM fungi on the growth and physiological status of Erythrina variegata Linn. grown under different water stress conditions. European Journal of Soil Biology 46, 151, 2010.

28. RAPPARINI, FRANCESCA, PEÑUELAS, JOSEP. Mycorrhizal fungi to alleviate drought stress on plant growth, In Use of Microbes for the Alleviation of Soil Stresses, 1, 21, Springer, 2014.

29. ZHANG Y., ZHONG C.L., CHEN Y., CHEN Z., JIANG Q.B., WU C., PINYOPUSARERK K. Improving drought tolerance of Casuarina equisetifolia seedlings by arbuscular mycorrhizas under glasshouse conditions. New Forests 40, 261, 2010.

30. YIGIT, NURCAN, SEVIK, HAKAN, CETIN, MEHMET, KAYA, NUR. Determination of the effect of drought stress on the seed germination in some plant species. Water stress in plants, 43, 2016.

31. SEVIK H., CETIN M. Effects of Water Stress on Seed Germination for Select Landscape Plants. Polish Journal of Environmental Studies 24, 689, 2015.

32. BALESTRASSE K.B., TOMARO M.L., BATLLE A., NORIEGA G.O. The role of 5-aminolevulinic acid in the response to cold stress in soybean plants. Phytochemistry 71, 2038, 2010.

33. ZHANG, BOWEN, LI, FUPING, XU, YONGLI, DONG, XIA, YUAN, XUETAO, XI, HONGCHAO. Drought Resistance of Five Herbs under Drought Stress Simulated by PEG-6000. Molecular Plant Breeding. 2018 [In Chinese].

34. ZHAO, LILI, WANG, PUCHANG, CHEN, CHAO, SONG, GAOXIANG, TANG, HUAJIANG. Effects of Exogenous $\mathrm{Ca} \sim(2+)$ on the Growth,Physiological Characters of Sophora viciifolia Seedlings in Karst Mountain Area Under the Drought Stress. Journal of Nuclear Agricultural Sciences. 2017 [In Chinese].

35. LIM, CHON C., ARORA, RAJEEV, TOWNSEND, EDWIN C. Comparing Gompertz and Richards Functions to Estimate Freezing Injury in Rhododendron Using Electrolyte Leakage. Journal of the American Society for Horticultural Science 123, 246, 1998.

36. BAO G.Z., AO Q., LI Q.Q., BAO Y.S., ZHENG Y., FENG X.X., DING X.M. Physiological Characteristics of Medicago sativa L. in Response to Acid Deposition and Freeze-Thaw Stress. Water Air and Soil Pollution 228, 2017. 
37. BIAN W.J., BAO G.Z., QIAN H.M., SONG Z.W., QI Z.M., ZHANG M.Y., CHEN W.W., DONG W.Y. Physiological Response Characteristics in Medicago sativa Under Freeze-Thaw and Deicing Salt Stress. Water Air and Soil Pollution 229, 2018.

38. GUO S. A. Effects of drought stress on relative water content of Leymus chinensis (Trin.) Tzvel. of different strains. Ningxia Journal of Agri and Fores Sci \& Tech, 56, 58-59, 74. 2015 [In Chinese].

39. DONG, XUBING, BI, HUANGAI, LIU, YEXIA, YU, JUNHUI, AI, XIZHEN. Relationship between cross adaptation to drought-low temperature and osmoregulation in cucumber seedlings. Scientia Agricultura Sinica 44, 335, 2011.

40. LI H.S. Principles and Techniques of Plant Physiological Biochemical Experiment. Beijing: Higher Education Press, 184, 2001 [In Chinese]

41. WANG X.K. Principle and Technology of Plant Physiological and Biochemical Experiments ( $2^{\text {nd }}$ Edition). Beijing: Higher Education Press, pp. 190-191+280. 2010.

42. MERAH O. Potential importance of water status traits for durum wheat improvement under Mediterranean conditions. Journal of Agricultural Science 137, 139, 2001.

43. YU L., WANG Y.R., TREVOR G.T.T., GEOFF A.T., HAN D.L. Physiological responses of different alfalfa varieties to drought stress. Acta Prataculturae Sinica 15, 75, 2006.

44. FAROOQ M., WAHID A., KOBAYASHI N., FUJITA D., BASRA S.M.A. Plant drought stress: effects, mechanisms and management. Agronomy for Sustainable Development 29, 185, 2009.

45. FLEXAS J., RIBAS-CARBO M., BOTA J., GALMES J., HENKLE M., MARTINEZ-CANELLAS S., MEDRANO $\mathrm{H}$. Decreased Rubisco activity during water stress is not induced by decreased relative water content but related to conditions of low stomatal conductance and chloroplast $\mathrm{CO}_{2}$ concentration. New Phytol 172, 73, 2006.

46. CHEN K., RENAUT J., SERGEANT K., WEI H., ARORA R. Proteomic changes associated with freeze-thaw injury and post-thaw recovery in onion (Allium cepa L.) scales. Plant Cell Environ 36, 892, 2013.

47. MORADI, ALI, YOUNESI, OMID. Influence of Arbuscular Mycorrhiza on Membrane Lipid Peroxidation and Soluble Sugar Content of Soybean under Salt Stress. Agriculturae Conspectus Scientificus 79, 227, 2015.

48. MILLER G., SUZUKI N., CIFTCI-YILMAZ S., MITTLER R. Reactive oxygen species homeostasis and signalling during drought and salinity stresses. Plant Cell Environ 33, 453, 2010.

49. LIU J. Study on the stress resistance of rye, triticale and elymus breviscapus seedlings under low temperature and drought stress. Journal of Tibet University. 2017 [In Chinese].

50. DING L., ZHAO H.M., ZENG W.J., LI Q., WANG Y., WANG S.Q. Physiological responses of five plants in northwest China arid area under drought stress. The Journal of Applied Ecology 28, 1455, 2017.
51. MISHRA M.K., SINGH G., TIWARI S., SINGH R., KUMARI N., MISRA P. Characterization of Arabidopsis sterol glycosyltransferase TTG15/UGT80B1 role during freeze and heat stress. Plant Signal Behav 10, e1075682, 2015.

52. FUKUDA A., TERAO T. QTLs for Shoot Length and Chlorophyll Content of Rice Seedlings Grown under LowTemperature Conditions, using a Cross between Indica and Japonica Cultivars. Plant Production Science 18, 128, 2015.

53. WISE R.R., OLSON A.J., SCHRADER S.M., SHARKEY T.D. Electron transport is the functional limitation of photosynthesis in field-grown Pima cotton plants at high temperature. Plant Cell and Environment 27, 717, 2004.

54. CRUZ DE CARVALHO M.H. Drought stress and reactive oxygen species: Production, scavenging and signaling. Plant Signal Behav 3, 156, 2008.

55. YANG A., AKHTAR S.S., AMJAD M., IQBAL S., JACOBSEN S.E. Growth and Physiological Responses of Quinoa to Drought and Temperature Stress. Journal of Agronomy and Crop Science 202, 445, 2016.

56. GILL P.K., SHARMA A.D., SINGH P., BHULLAR S.S. Changes in germination, growth and soluble sugar contents of Sorghum bicolor (L.) Moench seeds under various abiotic stresses. Plant Growth Regulation 40, 157, 2003.

57. WILLIAMS R.J., LEOPOLD A.C. The glassy state in corn embryos. Plant Physiol 89, 977, 1989.

58. ISHIBASHI Y., YAMAGUCHI H., YUASA T., IWAYAINOUE M., ARIMA S., ZHENG S.H. Hydrogen peroxide spraying alleviates drought stress in soybean plants. J Plant Physiol 168, 1562, 2011.

59. SASAKI, HIDEKAZU, ICHIMURA, KAZUO, OKADA, KUNIHIKO, ODA, MASAYUKI. Freezing tolerance and soluble sugar contents affected by water stress during cold-acclimation and de-acclimation in cabbage seedlings. Scientia Horticulturae 76, 161, 1998

60. TALAAT N.B., SHAWKY B.T., IBRAHIM A.S. Alleviation of drought-induced oxidative stress in maize (Zea mays L.) plants by dual application of 24-epibrassinolide and spermine. Environmental and Experimental Botany 113, 47, 2015.

61. BAEK, KWANG-HYUN, SKINNER, DANIEL $Z$. Production of reactive oxygen species by freezing stress and the protective roles of antioxidant enzymes in plants. Journal of Agricultural Chemistry and Environment 01, 34, 2012.

62. DOWGERT M.F., STEPONKUS P.L. Behavior of the Plasma Membrane of Isolated Protoplasts during a FreezeThaw Cycle. Plant Physiol 75, 1139, 1984.

63. CLOUTIER, YVES, SIMINOVITCH, DAVID. Correlation between Cold- and Drought-Induced Frost Hardiness in Winter Wheat and Rye Varieties. Plant Physiology 69, 256, 1982. 